Agro-Science Journal of Tropical Agriculture, Food, Environment and Extension Volume 17 Number 1 (January 2018) pp. 1 - 6

ISSN 1119-7455

\title{
EVALUATION OF POULTRY EGG MARKETING IN IKWUANO LOCAL GOVERNMENT AREA OF ABIA STATE, NIGERIA.
}

\author{
*Nse-Nelson F.A., Kurumeh J.C. and Osondu K.R. \\ Department of Agricultural Economics, \\ Michael Okpara University of Agriculture, Umudike, Nigeria \\ *Corresponding author's email: floxynse@gmail.com
}

\begin{abstract}
The study focused on evaluation of poultry egg marketing in Ikwuano Local Government Area (LGA) of Abia State. The specific objectives were to describe the socio-economic characteristics of egg marketers in the study area, determine the structure of the egg markets using the market concentration index, determine the costs and return of egg marketing and examine factors that influence the profitability of egg marketing. Two stage sampling technique was adopted for this study. Six communities were purposively selected from the ten communities in the LGA. Ten poultry egg marketers were selected from the six communities using simple random sampling technique. This made the total number of respondents to be sixty. Descriptive statistics, gini coefficient, costs and return analysis as well as multiple regression analysis were used to analyze the data collected. The results showed that majority (55\%) of the egg marketers were males who are still young and agile. They were also married with moderate household size. Many were dominantly farmers and acquired different levels of education. The concentration index showed that egg markets were also highly concentrated with core to perfect equality in size distribution. The result showed a net return of $\$ 215$ and marketing efficiency of 1.035. The coefficient for age, education, sex, and price had positive relationships with amount of sales while household size had a negative relationship with it. Variables that positively influence amount of sales from egg marketing should be considered and strengthened in policy implementation. There is need for guaranteed minimum prices for egg, to reduce price fluctuations and increase consumption of eggs.
\end{abstract}

Key words: poultry egg, market structure, marketing, Abia State

\section{INTRODUCTION}

Poultry is the term used for a collection of birds that are reared or hunted for a useful purpose by man. Poultry is one of the world's major and fastest growing sources of meat, representing over $22 \%$ of the meat production in 1989 (Mohammed et al., 2013; Chukwuji et al., 2006). In Nigeria, the demand for poultry egg has risen from 500,000 metric tonnes in 1980 to about 1,500000 metric tonnes in 2012 (FAO, 2012). Poultry eggs have assumed the role of providing much needed animal protein to mankind (Aihonsu and Sunmola, 1999). According to Alabi and Isah (2002), poultry eggs contributed to the palatability of many dishes by adding about the same amount of animal protein as pork and poultry meat. Poultry egg has attained industrial importance as a major ingredient in the baking of confectioneries. Also egg albumen is used in the making of shampoo, as well as book binding (Rahman and Yakubu, 2005). The need for animal protein in human diet has been recognized for long. In recent times, consumptions of most Nigerians have declined to an unbearable level. Malnutrition in human diet has been a major issue being debated on worldwide. Mostly in the developing countries, cases of poor health condition were traced to lack or inadequate animal protein in their diet.

Feeding on food of animal origin is probably the fastest economic and nutritional route to improvement in the nutritional status. Foods from animal origin have the capability of providing $35 \mathrm{~g}$ per capita of animal protein per day (Sani et al., 2003). Poultry eggs play a very useful role in bridging the protein gap in Nigeria. They are palatable and generally acceptable. This acceptability cuts across nearly all cultural and religious boundaries in the country. The importance of poultry to the national economy cannot be overemphasized, as it has become popular industry for the small holders that have great contribution to the economy of the country. The enterprise has assumed greater importance in improving the employment opportunity and animal protein 
production in Nigeria The production of eggs has been the factor of the greatest economic importance in poultry production thus the marketing of this product cannot be over emphasized.

Agricultural marketing dictates how often the producer will increase and /or produce their output/yield. A good marketing organization directs production along the most suitable needs of the consumers. The market mechanisms have to be efficient to be able to play the role of propelling yield (Esiobu et al., 2014b). Marketing is concerned with all stages of operatives which include the movement of commodities from the farms to the consumers. It involves the performance of all activities involved in the flow of goods and services from the point of initial production until they are in the hands of the ultimate consumers. Most of the eggs marketed and consumed in Nigeria come from poultry birds. Only little attention is given to other sources such as ducks, turkey, guinea fowl and geese because of their ability to lay few eggs (Rahman and Yakubu, 2002). As a result of the fragile nature of eggs, its marketing has been influenced by the difficulties in handling, transportation and distribution to the consuming unit. This has also influenced the cost of eggs in the market to a point that an average Nigeria cannot afford to buy eggs, and as a result failed to meet up with the standard nutrition requirement for protein intake per day or monthly. Due to the peculiar nature of egg, it becomes imperative to carry out a scientific survey of its marketing in the study area. The specific objectives of the study are to describe the socio-economic characteristics of the respondents, determine the structure of the egg markets, determine costs and return of egg marketing and examine the factors that influence the profitability of egg marketing.

\section{MATERIALS AND METHODS}

This study was carried out in Ikwuano Local Government Area of Abia State, Nigeria. The local government was created from the former Ikwuano-Umuahia local government area on the $27^{\text {th }}$ day of August 1991. Its headquarters is located at Isiala Oboro, which is approximately $14 \mathrm{~km}$ away from Umuahia town. Its land area is about $600 \mathrm{~km}^{2}$ with a population of over 33.993 people, with male $(16,965)$ and female $(17,028)$, (NPC, 2006). The population for the study includes all the poultry egg marketers in Ikwuano LGA, Abia State. The sampling frame is all poultry egg marketers in the communities selected for the study. Two stage sampling technique was adopted for this study. First, six (6) communities were purposively selected from ten (10) autonomous communities in Ikwuano LGA. Purposive sampling technique was adopted based on the concentration of egg marketers in these communities. Next, ten (10) poultry egg marketers were selected using simple random sampling from the six communities. This brought the total sample size to sixty (60). Primary data was used for the study and was collected through the administration of well-structured questionnaire to the respondents.

\section{Data Analysis}

Objective one was analyzed using descriptive statistical tools such as frequency distribution, percentages and mean. Objective two was analyzed by the use of gini coefficient which was used to determine the market structure of egg marketers in the study area. Gini coefficient is a measure of inequality in a distribution. It is used to measure the degree of market concentration. Market concentration is a key element in the market structure hence determines the type of competition. It is defined as a ratio with values between zero and one. A gini coefficient of 0 implies a perfect equality distribution; while a coefficient of 1 means perfect inequality distribution. The closer the gini coefficient is to zero, the greater the degree of equality, the lower the level of concentration of marketers and the more competitive the markets are (Agbugba et al., 2013). The gini coefficient model is specified below:

$$
\text { Ginicoefficient }=1-\sum X Y
$$

where $\mathrm{X}$ is the percentage of poultry egg sellers in the study area. $\mathrm{Y}$ is the cumulative percentage of their sales or revenue. Objective three which is on costs and return was analyzed using cost and return analysis and it include marketing margin and marketing efficiency. Marketing margin refers to the differences in price paid for a commodity at different stages of the marketing system (Olukosi et al., 2007). Therefore the marketing margin of the egg marketers is the difference between the price paid by the consumers and that received by the producer.

Marketing margin $=\mathrm{SP}-\mathrm{CP} / \mathrm{SP} \times 100$

where SP is selling price for egg marketers and $\mathrm{CP}$ is cost price for egg marketers. Marketing efficiency can be defined as the maximization of the ratio of output to input. Efficiency ratio can be expressed in physical or monetary terms, thus we have the following:

Marketing efficiency $=$ total return/total cost (3).

In other words, marketing efficiency is the output of marketing divided by the input of marketing that is the value of output divided by 
the input. Objective four was analyzed using a multiple regression analysis and the regression model is explicitly represented as:

$\mathrm{Y}=\mathrm{b}_{0}+\mathrm{b}_{1} \mathrm{X}_{1}+\mathrm{b}_{2} \mathrm{X}_{2}+\mathrm{b}_{3} \mathrm{X}_{3}+\mathrm{b}_{4} \mathrm{X}_{4}+\mathrm{b}_{5} \mathrm{X}_{5}+$ $\mathrm{b}_{6} \mathrm{X}_{6}+\mathrm{b}_{7} \mathrm{X}_{7}++\mathrm{b}_{8} \mathrm{X}_{8}+\mu_{\mathrm{i}}$

where

$\mathrm{Y}=$ Amount of sales (\#)

$\mathrm{X}_{1}=$ Age (in years)

$\mathrm{X}_{2}=$ Marketing experience Level of education (in years)

$\mathrm{X}_{3}=$ Level of education (in years)

$\mathrm{X}_{4}=$ Marital status

$\mathrm{X}_{5}=$ Household size (in number)

$\mathrm{X}_{6}=$ Transportation cost (\#)

$\mathrm{X}_{7}=$ Selling price (\#)

$\mathrm{X}_{8}=$ Storage cost (\#)

$\mathrm{e}=$ error term

Linear function

$\mathrm{Y}=\mathrm{b}_{0}+\mathrm{b}_{1} \mathrm{X}_{1}+\mathrm{b}_{2} \mathrm{X}_{2}+\mathrm{b}_{3} \mathrm{X}_{3}+\mathrm{b}_{4} \mathrm{X}_{4}+\mathrm{b}_{5} \mathrm{X}_{5}+$ $\mathrm{b}_{6} \mathrm{X}_{6}+\mathrm{b}_{7} \mathrm{X}_{7}+\mathrm{b}_{8} \mathrm{X}_{8}+\mathrm{e}$

Exponential function

$\log Y=b_{0}+b_{1} X_{1}+b_{2} X_{2}+b_{3} X_{3}+b_{4} X_{4}+b_{5}$ $\mathrm{X}_{5}+\mathrm{b}_{6} \mathrm{X}_{6}+\mathrm{b}_{7} \mathrm{X}_{7}+\mathrm{b}_{8} \mathrm{X}_{8}+\mathrm{e}$

Semi-log function

$\mathrm{Y}=\mathrm{b}_{0}+\mathrm{b}_{1} \log \mathrm{X}_{1}+\mathrm{b}_{2} \log \mathrm{X}_{2}+\mathrm{b}_{3} \log \mathrm{X}_{3}+\mathrm{b}_{4} \log \mathrm{X}_{4}$ $\ldots \ldots .+\log b_{8} x_{8}+e$

Double $\log$ function

$\log Y=b_{0}+b_{1} \log X_{1}+b_{2} \log X_{2}+b_{3} \log X_{3}+b_{4} \log X_{4}+b$

${ }_{5} \log \mathrm{X}_{5}+\ldots+\log \mathrm{b}_{8} \mathrm{X}_{8}+\mathrm{e}$

Four functional forms of the regression model were used which are the linear, exponential, semi-log and double log. The exponential functional form of the model was chosen as the lead equation based on the number of significant variables, the value of the $\mathrm{R}^{2}$ (coefficient of multiple determination), F-ratio and conformation of the variables to a priori expectation.

\section{RESULTS AND DISCUSSION \\ Socio-economic Characteristics of the Respondents}

The socio-economic characteristics of the respondents are presented in Table 1 . The result showed that majority of the egg marketers $(51 \%)$ were within the age range of 21-30 years. This indicates that they are in their middle and economically active age which could positively affect egg marketing in the study area. This is in line with the findings of Mafimisebi (2008) who noted that the age of egg marketers may influence their decision to increase resource allocation and their potential capability to work hard on their business to ensure success. The result shows that $55 \%$ of the egg marketers were males while $45 \%$ were females. The dominance of males could be due to the high level of physical activities such as lifting of crates that characterize the poultry egg business of which many females might not be able to cope with. Although in some cases, the input of the entrepreneur is not physical but is in coordinating and directing. The gender of the marketer is however expected to influence the efficiency of the unit because some of the inputs of the marketer though managerial, is as well physical sometimes (Afolabi et al., 2013).

Majority (53\%) of the respondents had marketing experience of 6-10 years. This implies that the marketers are relatively experienced in their business venture. This is in consonance with the findings of Mohammed et al. (2013) who found out a mean marketing experience of 5 years among egg marketers in Kuje Area Council in Abuja. An interesting finding of the study is that some $(31 \%)$ of the respondents were farmers, which implies that some of the marketers are have other sources of livelihood apart from marketing activities.

Majority $(60 \%)$ of the egg marketers had household size range of 4-6 persons. This implies that the study area is dominated by egg marketers with moderate household sizes. A moderate household size reduces the cost of hired labour and ensures availability of labour. This finding supports the result of Teklewold et al. (2006), Onubogu et al. (2013) and Esiobu et al. (2014a) who adopted moderate household size as a proxy or labour availability. Finally, the results showed that $63 \%$ of the respondents attained tertiary level of education. Exposure to high level of education predisposes marketers to innovation and better position for them to cope with emerging trends in business. It is also an added advantage in terms of achieving an efficient and sustainable poultry egg marketing (Esiobu et al., 2014b).

\section{Market Concentration}

The results in Table 2 showed the Gini coefficient measurement for egg marketers in the study area. The Gini coefficient reveals the existence of market concentration of egg marketers as depicted by a Gini coefficient of 0.50. Following from Okereke and Anthonio (1988), a Gini coefficient of $O$ indicates that there is perfect equality in size distribution of marketers and is equal to 1(one) when there is pure monopoly in the market. In practice, these extremes may not be realistic but often, the Gini coefficient falls between them. The market concentration therefore is high showing the possibility of competitive behavior and inequality in earnings of the marketers. The market structure depicts many sellers which describes a perfectly competitive market. 


\section{Cost and Returns Analysis of Egg} Marketing Per week in the Study Area

The result in Table 3 show the cost and returns analysis of egg marketing per week in the study area. The results show an average revenue of \#6,460.00 from 7.6 crates sold per week in the study area. The VC and FC were $\$ 5,916.00$ and \#328.57 respectively. A net return of 215.43 was realized which implies that egg marketing in the study area is profitable, although the margin is low. Comparing this finding with that of Mohammed et al. (2013) who reported 20\% in their study of egg marketing in Kuje Area Council (a Municipality of Federal Capital Territory, Abuja, Nigeria) this margin is low and the gap may be reflective of differences in cost of marketing in these areas. Marketing efficiency of 1.035 was obtained which means for every for every $\$ 1.00$ invested the egg marketing business, $1.035 \mathrm{k}$ is realized as profit. Determinants of Amount of Sales among Egg Marketers in Ikwuano LGA.

The result in Table 4 presents the regression estimates of the determinants of amount of sales among egg marketers in the study area the exponential functional form was chosen as the lead equation because of the high $R^{2}$ value and number of significant variables. The $R^{2}$ value of 0.8604 indicates that the variables in the model explain $86.04 \%$ of the variability in amount of sales. The $F$-value of 27.71 was highly significant at $1 \%$ level indicating a well fitted regression model. The coefficient for age was positive and significant at $1 \%$, an implication that a one year increase in age will lead to about $3 \%$ increase in egg profit. This is against a priori expectations probably because older egg marketers may seem to be more compelling while bargaining with their consumers. The coefficient for education was also positively signed and highly significant at $1 \%$ level. This implies that an increase in the educational attainment of the respondent is expected to lead to increase in the marketer's profit by $5 \%$. Onubogu et al. (2013) noted that higher level of education determines the quality of skills of respondents, their allocative abilities, efficiency and how well they are informed about the innovations and technologies around them. The coefficient for gender was positively signed and significant at $5 \%$ level of probability. This implies that the male egg marketers made more sales than their female counterparts. This may be because the males have more physical strength with more aggressive marketing abilities.
The coefficient for household size was negative and significant at $1 \%$, such that an additional household member will lead to a fall in sales of about $18 \%$. This is expected probably because, with large house holding they may consume more eggs their by leading to a reduction in number of eggs available for sale. Transportation cost and storage cost were negatively related to profits made from egg marketing. This implies that a decrease in transportation cost and storage cost will bring about an increase in net return accruing to egg marketers and vice versa. This is in consonance with Obasi and Amaechi (2013) who opined that a decrease in marketing cost leads to increase in net return. The coefficient for price was positively signed and highly significant at $1 \%$ level of probability. This implies that any increase in selling price of egg will lead to a corresponding increase in profit. This is in accordance with Nwaru and Iwuji (2005) and Offor and Nse-Nelson (2015) who observed that selling price was positively related to profit and net returns of poultry egg marketing in Umuahia South LGA of Abia State.

Table 1: Socio-economic characteristics of the respondents

\begin{tabular}{|c|c|c|}
\hline & Frequency & Percentage (\%) \\
\hline \multicolumn{3}{|l|}{ Age } \\
\hline $11-20$ & 8 & 13.33 \\
\hline $21-30$ & 31 & 51.66 \\
\hline $31-40$ & 17 & 28.33 \\
\hline $41-50$ & 4 & 6.67 \\
\hline Total & 60 & 100 \\
\hline \multicolumn{3}{|l|}{ Sex } \\
\hline Male & 33 & 55.00 \\
\hline Female & 27 & 45.00 \\
\hline Total & 60 & 100 \\
\hline \multicolumn{3}{|l|}{ Marketing } \\
\hline $1-5$ & 25 & 41.67 \\
\hline $6-10$ & 32 & 53.33 \\
\hline $10-15$ & 3 & 5.00 \\
\hline Total & 60 & 100 \\
\hline \multicolumn{3}{|c|}{ Occupational status } \\
\hline Civil servant & 16 & 26.67 \\
\hline Egg marketing & 3 & 5.00 \\
\hline Farming & 19 & 31.67 \\
\hline Schooling & 15 & 25.00 \\
\hline Trading & 7 & 11.67 \\
\hline Total & 60 & 100 \\
\hline \multicolumn{3}{|l|}{ Household size } \\
\hline $1-3$ & 9 & 15.00 \\
\hline $4-6$ & 36 & 60.00 \\
\hline $7-9$ & 7 & 11.67 \\
\hline $10-12$ & 8 & 13.33 \\
\hline Total & 60 & 100 \\
\hline \multicolumn{3}{|l|}{ Educational } \\
\hline \multicolumn{3}{|l|}{ Attainment } \\
\hline Primary & 4 & 6.67 \\
\hline Secondary & 18 & 30.00 \\
\hline Tertiary & 38 & 63.33 \\
\hline Total & 60 & 100 \\
\hline
\end{tabular}


Table 2: Percentage distribution of egg marketers by average size and total value of sales

\begin{tabular}{lcccccccc}
\hline $\begin{array}{l}\text { Range of sales } \\
(\mathrm{N})\end{array}$ & Frequency & $\begin{array}{c}\text { Cum } \\
\text { Frequency }\end{array}$ & $\begin{array}{c}\text { Proportion } \\
\text { of Cum. } \\
\text { Frequency }\end{array}$ & $1-\mathrm{N}\left(\mathrm{X}_{1}\right)$ & $\begin{array}{c}\text { Total value } \\
\text { Sale }\end{array}$ & Mean & $\mathrm{X}_{1}+-\mathrm{X}_{1}$ & $\begin{array}{c}\mathrm{N}_{1}\left(\mathrm{X}^{-1}\right) \\
(1-\mathrm{NX} \\
\left(\mathrm{X}_{1}+1-\mathrm{X}\right)\end{array}$ \\
\hline$<6,000$ & 8 & 8 & 0.13 & 0.87 & 30,000 & 3762.50 & $4,287.50$ & 484.92 \\
$6,000-10,000$ & 27 & 35 & 0.45 & 0.55 & 217,350 & 8,050 & 7,550 & 1868.63 \\
$11,000-15,000$ & 4 & 39 & 0.07 & 0.93 & 62400 & 15,600 & 400 & 260.4 \\
$16,000-20,000$ & 4 & 43 & 0.07 & 0.93 & 78,400 & 19,600 & 248152 & 161.57 \\
$21,000-25,000$ & 11 & 54 & 0.18 & 0.82 & 242,900 & $22,081.82$ & $37,251.51$ & $5,498.32$ \\
$>25$ & 6 & 60 & 0.6 & 0.4 & 356,000 & $59,333.33$ & 0 & 0 \\
Total & & & & & 987,150 & & & $8,273.84$ \\
Mean & & & & & $16,452.50$ & & & \\
\hline
\end{tabular}

Source: Survey field data, 2015, Gini coefficient $\mathrm{G}=0.5029=0.50$

Table 3: Cost and returns analysis of egg marketing in the study area

\begin{tabular}{lcccc}
\hline & Unit & Quantity & Unit Price (\#) & Total (\#) \\
\hline Total Revenue & Crate & 7.6 & 850 & $6,460.00$ \\
Cost & & & & \\
Variable Cost (VC) & Crate & 8 & 680 & $5,440.00$ \\
Egg Purchase & & & & 136 \\
Utility & & & 340 \\
Transportation & & & $5,916.00$ \\
Total Variable Cost & & & 328.57 \\
Fixed Cost (FC) & & & $6,244.57$ \\
Rent for store, market levy and depreciation on crates & & & 215.43 \\
Total cost (FC + VC) & & & 1.035 \\
Net Return = (TR-TC) & & & \\
Marketing efficiency (TR/TC) & & &
\end{tabular}

Table 4: Determinants of amount of sales among egg marketers in the study area

\begin{tabular}{lcccc}
\hline Variable & Linear & +Exponential & Double log & Semi-lolg \\
\hline Constant & $-512.879(-0.90)$ & $5.536\left(15.75^{* * * *}\right)^{\prime}$ & $1.526(1.03)$ & $-2988.791(-1.67)$ \\
Age & $46.484\left(3.53^{* * * *}\right)$ & $0.029\left(3.37^{* * * *}\right)$ & $1.025\left(4.26^{* * *}\right)$ & $1480.27\left(5.12^{* * * *}\right)$ \\
Education & $50.745\left(2.02^{*}\right)$ & $0.050\left(3.06^{* * * *}\right)$ & $-0.265(-1.21)$ & $-450.959\left(-1.71^{*}\right)$ \\
Sex & $270.814(1.04) 1$ & $0.406\left(2.39^{* *}\right)$ & $-0.090(-0.63)$ & $-287.263(-1.66)$ \\
Marital status & $-89.392(-0.73)$ & $-0.133(-1.66)$ & $-0.000(-0.12)$ & $65.011(0.66)$ \\
Household size & $-171.264\left(-3.20^{* * *}\right)$ & $-0.179\left(-5.11^{* * * *}\right)$ & $-0.238(-1.30)$ & $-65.536(-0.30)$ \\
Trans Cost & $-0.004(-0.21)$ & $-0.00001(-1.06)$ & $0.226\left(2.62^{* * * *}\right)$ & $347.906\left(3.94^{* * * *}\right)$ \\
Price & $1.303\left(1.91^{*}\right)$ & $0.0015\left(3.47^{* * *}\right)$ & $0.623\left(2.80^{* * *}\right)$ & $373.906(1.39)$ \\
Storage Cost & $-0.105\left(-2.0^{*}\right)$ & $-0.0003(-0.94)$ & $-0.348\left(-8.45^{* * *}\right)$ & $-605.693\left(-7.85^{* * *}\right)$ \\
$\mathrm{R}^{2}$ & 0.7863 & 0.8604 & 0.8420 & 0.8593 \\
$\mathrm{R}$ & 0.7424 & 0.8597 & 0.8096 & 0.8293 \\
$\mathrm{~F}$ & $1.94^{* * * *}$ & $27.7^{* * * *}$ & $25.97^{* * *}$ & $29.54^{* * * *}$ \\
\hline $\mathrm{S}$ & &
\end{tabular}

Source: Field data 2015 . "and "means significant at $10 \%, 5 \%$ and $1 \%$ level of probability, + is the lead equation and figures in parentheses are the $\mathrm{t}$-values.

\section{CONCLUSION}

Poultry egg marketing in the study is highly concentrated, perfectly competitive and profitable though the marketing margin was low. Marketing efficiency of 1.035 was obtained and this helps the marketers to maintain return to capital invested in the marketing activity. Variables that positively influence amount of sales from egg marketing should be considered and strengthened in policy implementation which will lead to more people taking up egg marketing as a means of livelihood.

\section{REFERENCES}

Afolabi I.O. (2007) Evaluation of poultry egg marketing in South Western Nigeria. International Journal of Poultry Science, 6, 362366

Afolabi O.I., Adegbite, D.A., Ashaolu O.F. and Akinnbode S.O. (2013). Profitability and resource-use efficiency in poultry egg farming in Ogun State. Nigeria. African Journal of Business Management, 7 (16), 1536-1540

Agbugba I.K. Nweze, N.J. Achike A.I. and Obi A. (2013). Market Structure, conduct, channel and margin of dry season okra vegetable in SouthEastern Nigeria. International Conference on Food and Agricultural Sciences IPCBEE. 55: 7378 
Aihonsu J.O.Y. and Sunmola M.A. (1999). Optimal laying period for profitable and sustainable egg production. Ife Journal of Agriculture, 20: 67-80

Alabi R.A. and Isah A.O. (2002). Poultry production constraints: The case of Esan West L.G.A of Edo State Nigeria. African Journal of Livestock Extension, 1, 58-61

Chukwuji C.O. Inoni O.E.. Ogisi O.D. and Oyaide W.J (2006) A quantitative determination of allocative efficiency in broiler production in Delta State, Nigeria. Agricultural conspectus scientificus 7 (11), 21-26

Esiobu N.S. Nwosu C.S. and Onubuogu G.C. (2014a). Economics of pineapple marketing in Owerri municipal council area, Imo State, Nigeria. International Journal of Applied Research and Technology, 3 (5), 3-12

Esiobu N.S., Onubuogu G.C.and Okoli B.N. (2014b). Determinants of income from poultry egg production in Imo State, Nigeria: An econometric approach. Global Advanced Research Journal of Agricultural Science, 3 (7), 186-199

FAO (2012) Food and Agricultural Organization statistic online issue. www.fao.org Mohammed. A.B. Mohammed S.A. Ayanlere A.F. and Afolabi O.K. (2013). Evaluation of poultry egg marketing in Kuje Area Council Municipality of FCT Abuja, Nigeria. Greener Journal of Agricultural Science. 3 (1), 068-072

NPC (2006) National Population Commission, Abuja, Nigeria

Nwaru J.C. and Iwuji O. 2005. Marketing margin and their determinants in plantain marketing in Owerri Agricultural Zone of Imo State in Nigeria. Agricultural research for improved Agriculture in Nigeria (Eds)
Obasi I.O. and Amaechi E.O. (2013). Efficiency of poultry marketers in Owerri Municipal, Imo State, Nigeria. Research Journal of Agriculture and Environmental Management, 2 (8), 197- 201

Offor E.I.,and Nse-Nelson F.A. (2015). Marketing efficiency of poultry eggs in Umuahia South Local Government Area of Abia State, Nigeria. International Journal of Applied Research and Technology, 4 (6), 3-7

Okereke O. and Anthonio Q.B.O. (1988) The structural characteristics of the market for grains in Eastern Nigeria", In Adekanye, T.O. (ed). Readings in Agricultural Marketing, Lagos: Longman Publishers

Olukosi J.O. Isitof S.U. and Ode M.O. 2007. introduction to agricultural marketing; principles and application. $3^{\text {rd }}$ edition. G. U. Publishers, Abuja: Nigeria. Pp 47-57

Onubuogu G.C. Chidebelu S.A.N. and Eboh E.C. (2013). Enterprise type, size and allocative efficiency of broiler production in Imo State, Nigeria. International Journal of Applied Research Technology, 2 (6), 10-19

Rahman S.A. and Yakubu A. (2005) Analysis of poultry egg production, distribution and consumption in parts of Nasarawa State, Nigeria. International Journal of Natural Applied Science, 1 (1), 1 - 4

Sani R.M., Tahir I., and Kushwaha S. (2003). Economics of poultry production in Bauchi State: A case study of Bauchi Local Government Area. Nigeria Journal of Animal Production, 27 (1), 109-113

Teklewold H., Dadi L.A., Yami, A., and Dana N., (2006). Determinants of adoption of poultry technology: A Double Hurdle Approach. Livestock Research for Rural Development 18 (3) 